\title{
High-Affinity Uptake of Noradrenaline in Quail Dorsal Root Ganglion Cells That Express Tyrosine Hydroxylase Immunoreactivity in vitro
}

\author{
Zhi-Gang Xue and Julian Smith \\ Institut d'Embryologie du CNRS et du Collège de France, 94736 Nogent-sur-Marne Cedex, France
}

\begin{abstract}
During embryonic life, avian sensory ganglia contain cells with the potential to express, under appropriate experimental conditions, a number of properties characteristic of autonomic sympathetic neurons. Thus, cells capable of synthesizing noradrenaline (NA) from tyrosine differentiate when dorsal root ganglia (DRG) from 10-15 d embryonic quail are grown in culture (Xue et al., 1985a, b). In the present study, we show that cultures of DRG from $10 \mathrm{~d}$ embryos can take up ${ }^{3} \mathrm{H}-\mathrm{NA}$ by a high-affinity $\left(K_{\mathrm{m}}=1.0 \mu \mathrm{M}\right)$, temperature-dependent process that can be inhibited by desmethylimipramine. By means of combined immunocytochemistry and autoradiography, it was demonstrated that the majority (70$80 \%$ ) of the tyrosine hydroxylase (TH)-immunoreactive cells that developed in the cultures possessed a transport system for NA. Catecholamine (CA) uptake also occurred in a small, but relatively constant, number of TH-negative cells, but was absent from substance P-containing neurons. In contrast to $\mathrm{TH}$, which appears only after 3-4 $\mathrm{d}$ in vitro, cells capable of taking up NA with high affinity were found in DRG cultures after only a few hours, and a small number (less than $0.5 \%$ of the total cell population) was detected in freshly removed, uncultured ganglia. Such cells did not react with antibodies directed against substance $P$ or neurofilament proteins. We conclude that autonomic precursors are identifiable in a subset of non-neuronal DRG cells, prior to full expression of a noradrenergic phenotype, by their possession of a high-affinity uptake system for CA.
\end{abstract}

Recent evidence suggests that autonomic and sensory ganglia arise during embryogenesis from precursor cells that are developmentally restricted to the "autonomic" and "sensory" differentiation pathways, respectively (Le Douarin, 1984, 1986). The segregation of the 2 cell lines occurs within the confines of the neural crest itself, or as the precursors leave the neural primordium for the sites of peripheral ganglion formation. Since there are no reasons to believe that such precommitment affects

\footnotetext{
Received Jan. 9, 1987; revised Sept. 1, 1987; accepted Sept. 11, 1987.

This work was supported by the Centre National de la Recherche Scientifique, the Institut National de la Santé et de la Recherche Médicale, the Fondation pour la Recherche Médicale Française, and the Ligue contre le Cancer, and was aided by Basic Research Grant 1-866 from the March of Dimes Birth Defects Foundation. The authors thank Professor N. M. Le Douarin for her interest and support and are grateful to Dr. D. Paulin for the gift of antibodies. They also wish to acknowledge the help of Mrs. E. Bourson and Mr. Y. Rantier in the preparation of the manuscript.

Correspondence should be addressed to Zhi-Gang Xue, Institut d'Embryologie du CNRS et du Collège de France, 49bis, Avenue de la Belle-Gabrielle, 94736 Nogent-sur-Marne Cedex, France.

Copyright (C) 1988 Society for Neuroscience $0270-6474 / 88 / 030806-08 \$ 02.00 / 0$
}

the migratory behavior of the cells, it follows that the peripheral ganglion rudiments are initially composed of a mixed population of precursors of autonomic and sensory type; the subsequent differentiation of the appropriate subpopulation would then result from the selective local action of tissue-derived signals, whereas the inappropriate precursor pool would remain in a latent state within the developing ganglion for a length of time that would depend on the stringency of its requirements for survival.

By means of in vivo and in vitro experimentation, it has proved possible to reveal the existence of an autonomic precursor cell population in developing sensory ganglia right up to the end of the embryonic incubation period. Thus, autonomic properties are expressed by cells originating from the non-neuronal population of the transplant when fragments of quail dorsal root ganglia (DRG) or nodose ganglion are grafted into young chick embryo recipients (Ayer-Le Lièvre and Le Douarin, 1982; Schweizer et al., 1983). A similar phenomenon occurs in vitro when quail DRG, taken at embryonic days 10-15 (E10-E15), are grown as dissociated cells in medium supplemented with chick embryo extract; cells of autonomic sympathetic type, defined by their immunoreactivity to tyrosine hydroxylase (TH) and their ability to synthesize and store noradrenaline (NA) from exogenous tyrosine, arise in such cultures. Evidence was provided that this appearance de novo of a phenotype that is undetectable in quail DRG during normal development is not the consequence of a phenotypic switch at the level of the ganglionic postmitotic neurons, but the result of the differentiation of cells that, at the time of plating, are part of the non-neuronal population (Xue et al., 1985a, b).

Cells able to synthesize and store catecholamine (CA) in DRG cultures appear only after a lag of $3 \mathrm{~d}$ (Xuc ct al., 1985a). In contrast, it has been found recently that another typical component of the noradrenergic phenotype, the transport mechanism enabling extracellular CA to be taken up and concentrated, is present in a large proportion of chick non-neuronal DRG cells after only $24 \mathrm{hr}$ of culture (Rohrer, 1985). The experiments described in the present paper were undertaken to examine, in cultures of dissociated DRG, the expression of a high-affinity uptake system for NA, its distribution within the ganglion cell population, and its relation to the differentiation of cells capable of synthesizing the CA.

\section{Materials and Methods \\ Cell culture}

DRG were removed from E10 Japanese quail embryos, dissociated and cultured on collagen-coated glass coverslips in medium supplemented with 10\% E11 chick embryo extract. The techniques involved have been described in detail elsewhere (Xue et al., 1985b, 1987). 

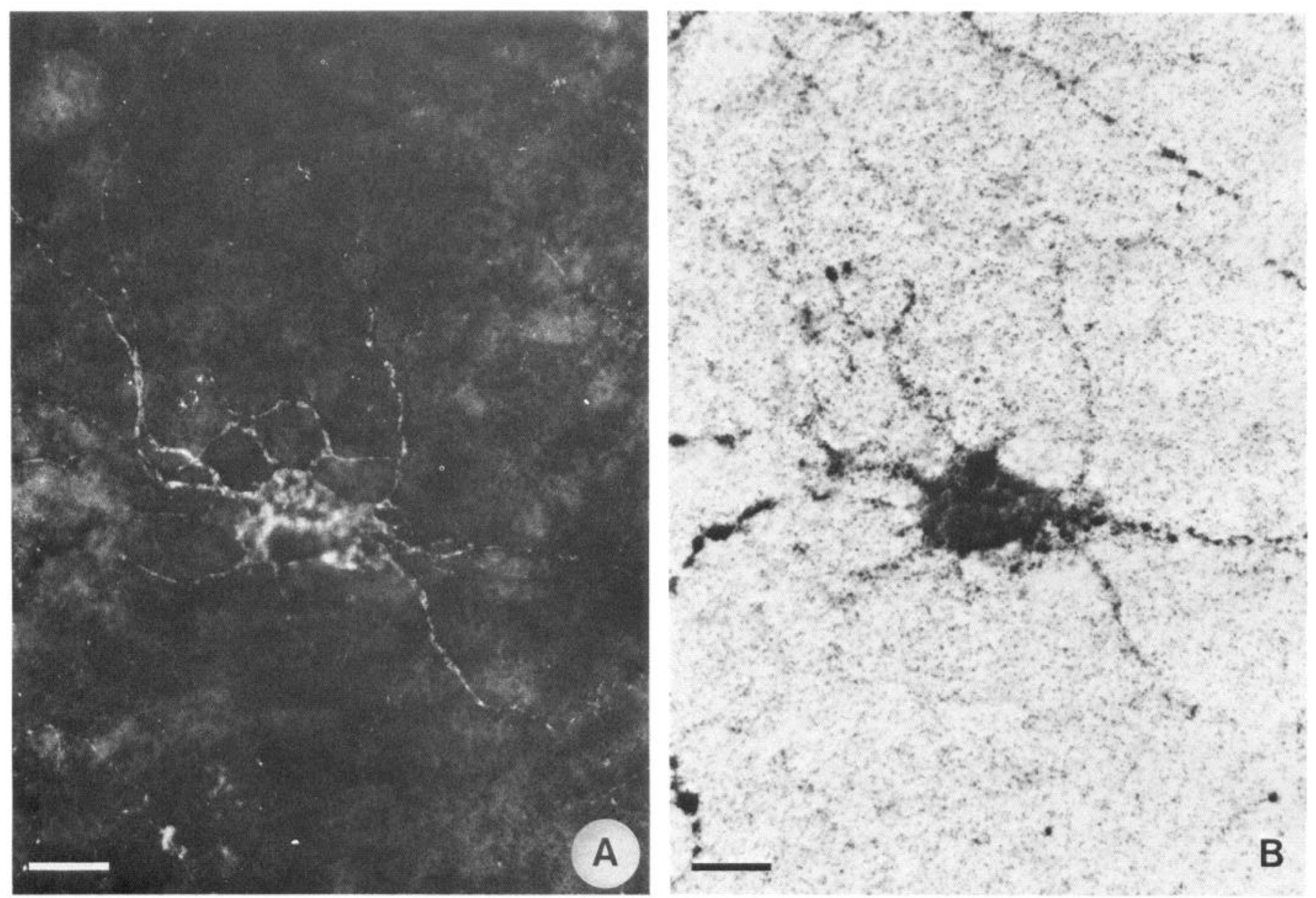

Figure 1. CA uptake by a TH-positive cell in a $4 \mathrm{~d}$ culture of E10 quail DRG. $A$, TH immunofluorescence. $B,{ }^{3} \mathrm{H}-\mathrm{NA}$ uptake. Scale bars, $20 \mu \mathrm{m}$.

\section{Antibodies}

The following primary antibodies were used: rabbit polyclonal antibody to bovine TH (Eugene Tech International, Allendale, NJ), rat monoclonal antibody to the carboxy-terminal fragment of substance P (SeraLab, France), and a mixture of 2 mouse monoclonal antibodies directed, respectively, against the 70 and $210 \mathrm{kDa}$ subunits of bovine neurofilaments (a gift from Dr. D. Paulin, Institut Pasteur, Paris). Secondary antibodies were fluorescein isothiocyanate (FITC)-labeled goat anti-rabbit Ig, FITC goat anti-mouse Ig (both from Nordic, Tilburg, The Netherlands) and tetramethyl rhodamine isothiocyanate (TRITC)-labeled goat anti-rat IgG (Cappel Laboratories, USA).

\section{Immunocytochemistry}

Immunolabeling of paraformaldehyde-fixed cells by treatment with antiTH (dilution 1:120) or anti-substance $\mathrm{P}$ (dilution 1:500) was performed as described previously (Xue et al., 1985b, 1987), and immunoreaction with anti-neurofilament (dilution 1:200) was carried out in the same manner. The appropriate secondary antibodies were applied at a dilution of $1: 50$.

\section{NA uptake}

Uptake followed by autoradiography. Cultures were rinsed in solution A $\left(\mathrm{Ca}^{2+} / \mathrm{Mg}^{2+}\right.$-free PBS, $1 \mathrm{~mm}$ ascorbic acid) and then incubated for $120 \mathrm{~min}$ at $37^{\circ} \mathrm{C}$ with $0.5 \times 10^{-6} \mathrm{M} \mathrm{L}-\left(7,8^{-3} \mathrm{H}\right)-\mathrm{NA}(30-50 \mathrm{Ci} / \mathrm{mmol}$, Amersham) made up in the same solution. The coverslips were then rinsed 3 times with solution A, containing $24 \mathrm{~mm}$ DL-NA, and fixed with $4 \%$ paraformaldehyde in $\mathrm{Ca}^{2+} / \mathrm{Mg}^{2+}$-free PBS. After rinsing, the preparations were processed, either directly for autoradiography, or for immunocytochemistry followed by autoradiography, as already described (Xue et al., 1985a). Exposure time was 10-14 d.
Freshly removed DRG (approximately 25/experiment) were washed in solution $\mathrm{A}$ and incubated with ${ }^{3} \mathrm{H}-\mathrm{NA}$ as detailed above, except that the incubation time was reduced to $60 \mathrm{~min}$. After rinsing in solution A, the ganglia were dissociated in $0.25 \%$ trypsin (Gibco) at $37^{\circ} \mathrm{C}$ for 20

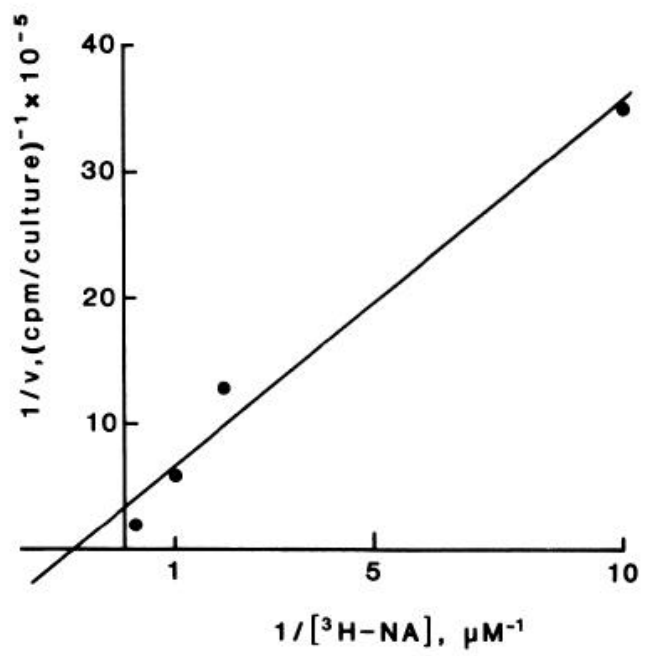

Figure 2. Concentration-dependence of NA accumulation. Velocity of NA uptake was measured by incubating $4 \mathrm{~d}$ cultures of E10 quail DRG for $10 \mathrm{~min}$ with a range of ${ }^{3} \mathrm{H}-\mathrm{NA}$ concentrations. The graph shows Lineweaver-Burk treatment of the data obtained. A straight line was drawn through the points by the method of least-squares. 


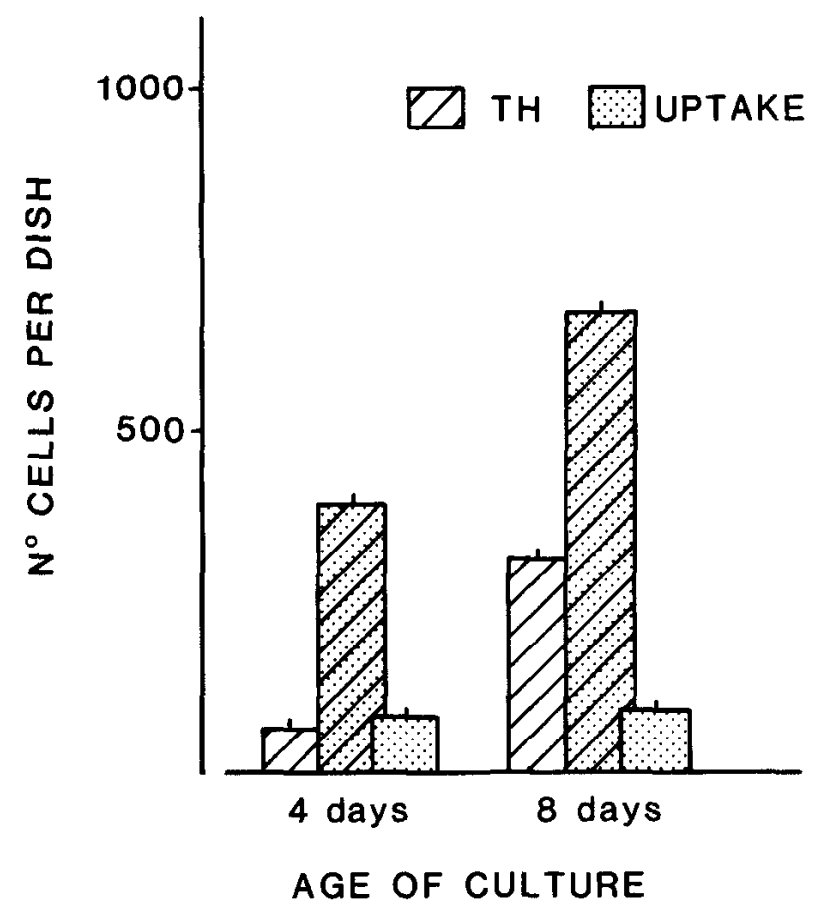

Figure 3. Quantitative comparison of the subsets of cultured DRG cells expressing TH immunoreactivity and/or CA-uptake properties. Data are means \pm SEM of counts performed on 3 separate cultures at both time points. All dishes were initially seeded with $7 \times 10^{4}$ dissociated E10 DRG cells.

min, at the end of which time the enzymic reaction was stopped by the addition of $10 \%$ heat-inactivated horse scrum. The resulting cell suspension was rinsed 3 times with $24 \mathrm{~mm}$ DL-NA in solution A and fixed for $1 \mathrm{hr}$ in $4 \%$ paraformaldehyde. The fixed cells were removed by centrifugation, resuspended in a minimal volume of PBS, and transferred to a glass slide to which they were attached by forced air drying for approximately $1 \mathrm{hr}$. The slides were then processed for autoradiography as before.

Both with cultures and with fresh ganglia, control incubations were carried out in the presence of $0.5 \times 10^{-6} \mathrm{M}$ desmethylimipramine (DMI), a specific inhibitor of high-affinity NA uptake (Glowinski and Axelrod, 1964: Iversen, 1973)

Kinetic studies. Cultures were incubated for $10 \mathrm{~min}$ at $37^{\circ} \mathrm{C}$ with 200 $\mu$ of ${ }^{3} \mathrm{H}$-NA $(37 \mathrm{Ci} / \mathrm{mmol})$ at different concentrations in solution A. After rinsing 3 times in solution A, the cells were lysed in PBS containing $1 \%$ sodium dodecyl sulfate and the lysate was transferred quantitatively to $20 \mathrm{ml}$ vials. Radioactivity was determined by liquid-scintillation spectrometry.

Uptake of ${ }^{3} \mathrm{H}-\mathrm{NA}$ into freshly dissected DRG (10 ganglia/assay) was measured in a similar manner except that disruption of the radioactive ganglion was expedited by ultrasonication.

A parallel series of experiments was performed in which incubation with ${ }^{3} \mathrm{H}-\mathrm{NA}$ was carried out at $4^{\circ} \mathrm{C}$. All determinations were made in triplicate.

\section{Results}

A CA-uptake system is present in $T H$-positive cells differentiating in $D R G$ cultures

When DRG cultures that had been grown for $4 \mathrm{~d}$ or more were incubated for $120 \mathrm{~min}$ with $0.5 \times 10^{-6} \mathrm{M}^{3} \mathrm{H}-\mathrm{NA}$, accumulation of the radioactive amine could be demonstrated in cells that were immunocytochemically TH-positive (Fig. 1, $A, B$ ). Silver grains were usually uniformly distributed over the cell bodies and their numerous processes. In control experiments performed to verify the specificity of the uptake mechanism, cultures were incubated with ${ }^{3} \mathrm{H}-\mathrm{NA}$ in the presence of the inhibitor DMI; no labeling above background levels was seen in any cells.
Table 1. Number of DRG cells taking up ${ }^{3} \mathrm{H}-\mathrm{NA}$ in isolated, intact ganglia and in short-term cultures prior to the appearance of $T H$. The results are means \pm SEM

\begin{tabular}{ll}
$\begin{array}{l}\text { Age of culture } \\
(\mathrm{hr})\end{array}$ & $\begin{array}{l}\text { No. of cells taking up } \\
\text { 'H-noradrenaline }\end{array}$ \\
\hline $0(n=5)$ & $227 \pm 48^{a}$ \\
$12(n=3)$ & $110 \pm 7^{b}$ \\
$48(n=3)$ & $182 \pm 11^{b}$
\end{tabular}

${ }^{a}$ Per $7 \times 10^{4}$ cells in the dissociated cell suspension.

${ }^{b}$ Per $7 \times 10^{4}$ cells initially plated.

That the CA was indeed being transported by a high-affinity process was demonstrated by incubating $4 \mathrm{~d}$ cultures with concentrations of ${ }^{3} \mathrm{H}-\mathrm{NA}$ ranging from 0.1 to $5 \mu \mathrm{M}$ and determining the amount of radioactivity in the cells after $10 \mathrm{~min}$. A Lineweaver-Burk plot of the data obtained reveals an apparent $K_{\mathrm{m}}$ of approximately $1 \mu \mathrm{M}$ (Fig. 2). At this concentration of NA, uptake at $4^{\circ} \mathrm{C}$ was less than $10 \%$ of that at $37^{\circ} \mathrm{C}$ (data not shown).

Figure 3 compares quantitative data relating to the expression of CA-uptake properties and TH immunoreactivity in 2 series of E10 DRG cultures grown, respectively, for 4 and $8 \mathrm{~d}$. At both time points, CA uplake and TH overlapped in a substantial number of cells. The coincidence was not total, however; on average, $82 \%$ of the $\mathrm{TH}$-immunoreactive cells present in $4 \mathrm{~d}$ cultures were found to take up NA and this figure decreased somewhat (to $68 \%$ ) as the cultures aged, although the absolute number of cells associating $\mathrm{TH}$ and uptake increased significantly. The great majority of cells that took up CA (81 and $88 \%$ at 4 and $8 \mathrm{~d}$, respectively) were TH-positive, but a small and relatively constant number contained no detectable enzyme. Irrespective of whether they were immunocytochemically THpositive or -negative, all cells that accumulated ${ }^{3} \mathrm{H}-\mathrm{NA}$ from the medium had a similar multipolar morphology

Noradrenergic cells that develop in DRG cultures do not display substance P-like immunoreactivity

A class of neurons in spinal and proximal cranial sensory ganglia is characterized by its substance $P$ content. In the DRG, it is typically the "small dark" neuronal subpopulation that displays immunoreactivity for the neuropeptide (Fontaine-Pérus et al., 1985; New and Mudge, 1986). Under the culture conditions used here, virtually all DRG cells with a bi- or tripolar neuronal morphology react positively with a monoclonal antibody directed against substance $P$. Using double-immunofluorescence labeling with the appropriate antibodies, we have shown that substance P-containing neurons do not display TH immunoreactivity (Xue et al., 1987). The 2 markers thus apparently define distinct cell populations. Likcwise, cells displaying substance P-like immunoreactivity were never found to have taken up NA when cultures of 4-10 d were incubated with the labeled CA (Fig. 4, $A, B$ ).

Organization of a CA-uptake system precedes the expression of CA-synthesizing ability and is confined to a subset of non-neuronal ganglion cells

Regardless of the age of the embryos from which the ganglia are taken, neither TH immunoreactivity nor the synthesis of $\mathrm{CA}$ from a radioactive precursor can be detected in cultured DRG before 3-4 d in vitro (Xue et al., 1985a, b). In contrast, cells with CA-uptake properties could be seen after much shorter 

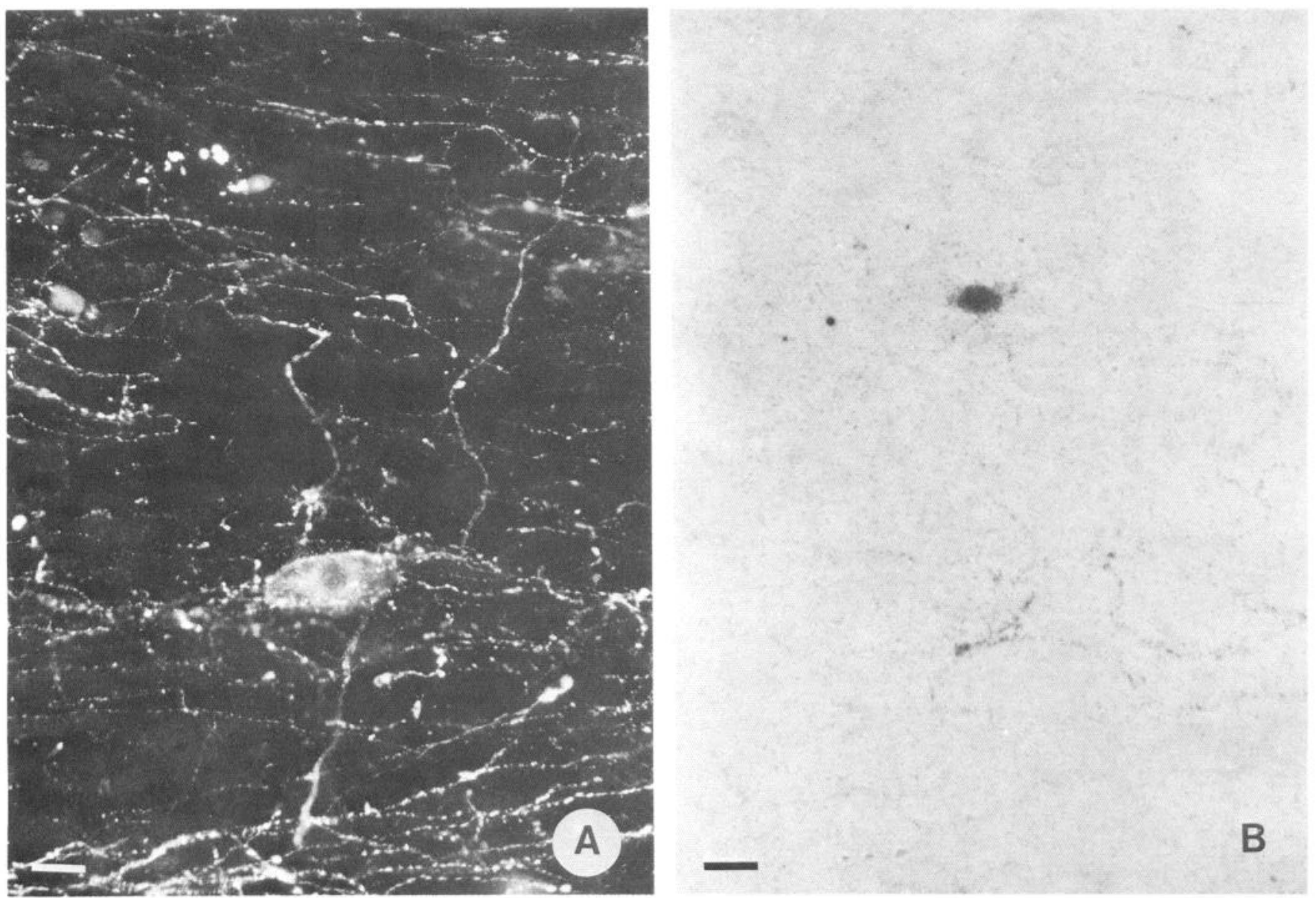

Figure 4. Five d culture of DRG processed to reveal substance $\mathrm{P}$ immunoreactivity and ${ }^{3} \mathrm{H}-\mathrm{NA}$ uptake. Substance P-positive neurons $(A)$ do not take up NA $(B)$. Scale bars, $20 \mu \mathrm{m}$.

periods in culture. Thus, after $2 \mathrm{~d}$, approximately 200 cells (of the $7 \times 10^{4}$ initially plated) took up ${ }^{3} \mathrm{H}-\mathrm{NA}$ by a high-affinity process, and a similar number did so in cultures grown for only $12 \mathrm{hr}$, a length of time just sufficient to allow adequate attachment to the substrate. These results suggested that cells with the ability to accumulate CA might already exist within the DRG in situ, and, indeed, when freshly dissected DRG were incubated in radioactive NA, approximately $0.3 \%$ of the cells in the suspension obtained by subsequent tryptic dissociation were found to have taken up the amine by a DMI-inhibitable mechanism (Table 1; Fig. 5).

As in the case of cultured cells, the entry of NA into noncultured DRG was strongly depressed by lowering the temperature (Fig. 6A). Corrected for uptake measured at $4^{\circ} \mathrm{C}$, the apparent $K_{\mathrm{m}}$ for NA transport at $37^{\circ} \mathrm{C}$ in freshly removed DRG was approximately $1.5 \mu \mathrm{M}$ (Fig. $6 B$ ).

In size and shape, the cells with uptake ability present in young cultures of E10 DRG were indistinguishable from those that displayed TH immunoreactivity several days later. Immunocytochemical staining for substance $\mathrm{P}$ at $48 \mathrm{hr}$ revealed that, as in the case of older cultures, the cells that contained the neuropeptide and those that possessed a high-affinity CA-uptake system constituted entirely nonoverlapping populations (Fig. 7, $A, B)$. Although this observation suggests that the cells that exhibit uptake properties prior to the appearance of $\mathrm{TH}$ belong to the non-neuronal population of the DRG, a more unequivocal demonstration was provided when $15 \mathrm{hr}$ cultures were exposed for $2 \mathrm{hr}$ to ${ }^{3} \mathrm{H}-\mathrm{NA}$ and then processed consecutively for immunocytochemistry, using both an antiserum directed against neurofilament proteins and autoradiography. Many brilliantly fluorescent, round cell bodies, united by more faintly stained fibers, could be seen. None of these cells was found to have accumulated radioactive $\mathrm{CA}$. Cells over which silver grains were heavily concentrated all clearly lacked neurofilament immunoreactivity (Fig. 7, $C, D$ ).

\section{Discussion}

The presence of a transport system with a high affinity for NA is characteristic of noradrenergic nerve cells in the central and peripheral nervous systems. The transport process, termed "Uptake, ," can be blocked by a number of specific inhibitors, including DMI (Iversen, 1973). The demonstration that THpositive cells differentiating in cultures of dissociated DRG take up exogenous NA in a similar manner adds a further feature to the inventory of noradrenergic, sympathetic-type properties that they have been found to possess (Xue et al., 1985a, b).

In peripheral noradrenergic neurons, the entire cell (terminals, axon, and perikaryon) can take up and store CA (Hamberger et al., 1964). Our autoradiograms revealed a fairly uniform distribution of radioactivity over the cell bodies and processes of $\mathrm{TH}$-immunoreactive cells. A similar pattern of labeling, after a short exposure to ${ }^{3} \mathrm{H}-\mathrm{NA}$, has been observed in cultured sym- 
Figure 5. Cell with a CA-uptake system in a suspension prepared from freshly dissected E10 quail DRG. $A,{ }^{3} \mathrm{H}-$ NA uptake. $B$, Phase-contrast view of the same field. Scale bars, $10 \mu \mathrm{m}$.
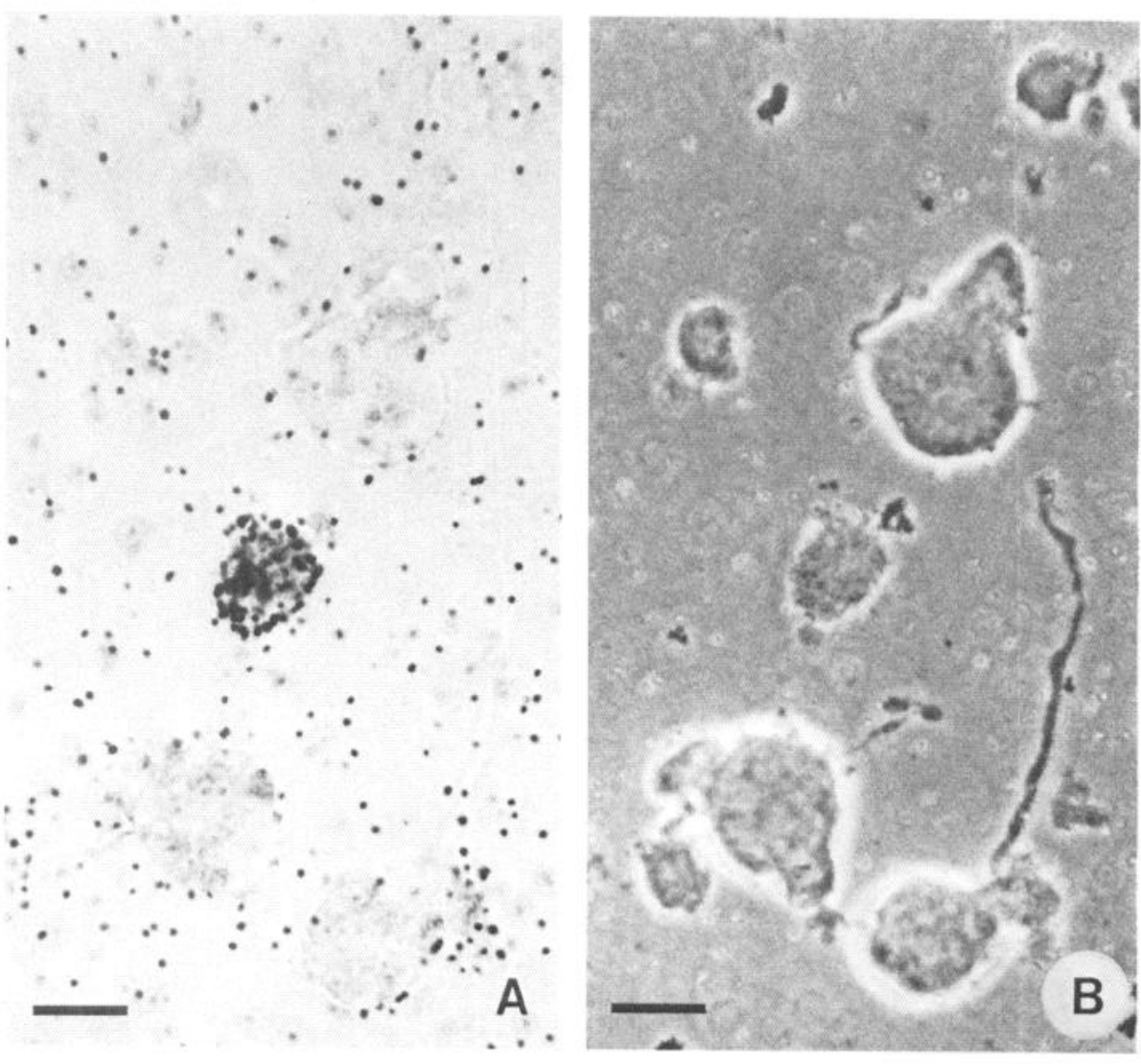
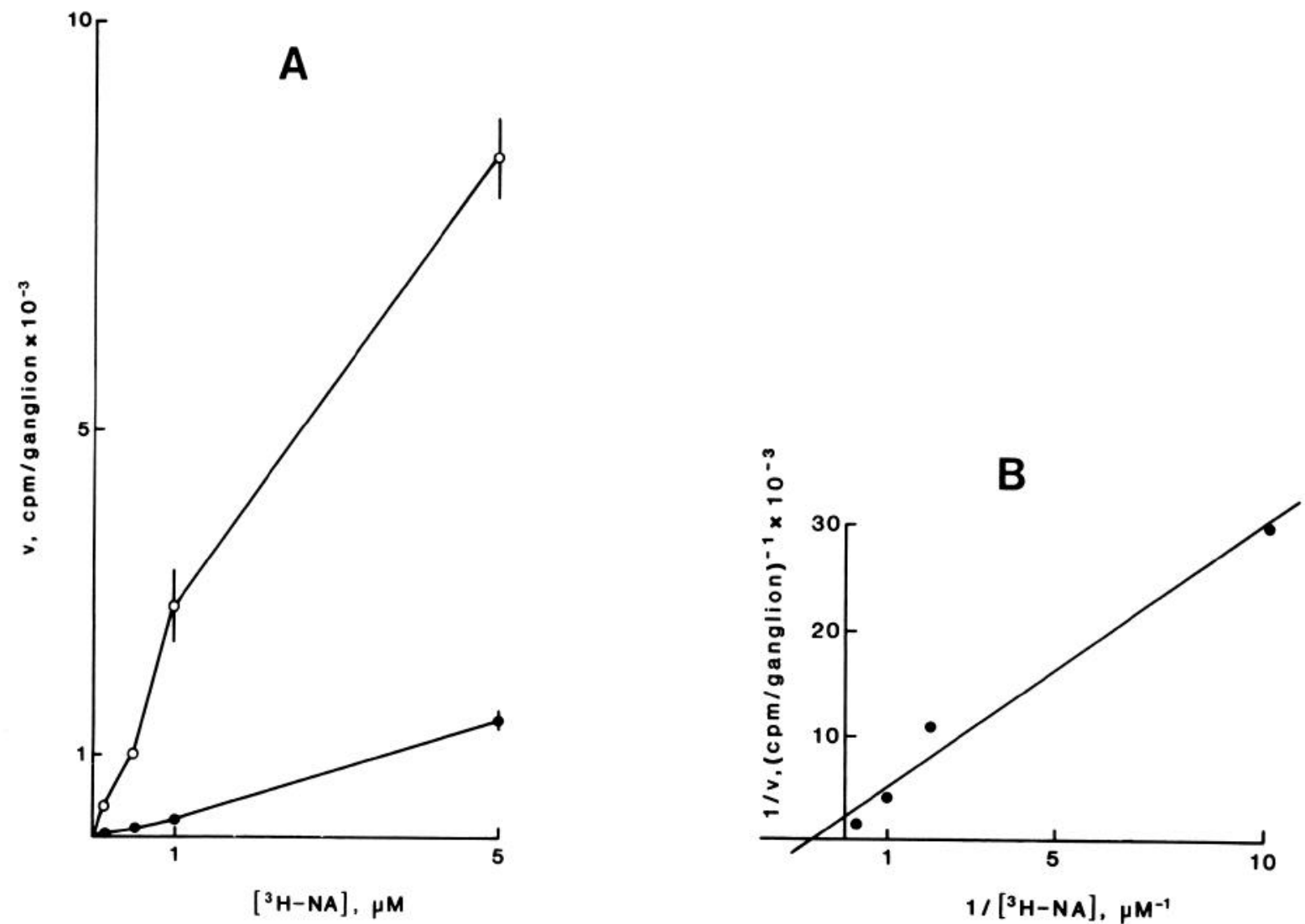

Figure 6. Concentration dependence of ${ }^{3} \mathrm{H}-\mathrm{NA}$ uptake in freshly dissected DRG. $A$, Velocity of uptake at $37(\mathrm{O})$ and $4^{\circ} \mathrm{C}(\bullet)$ plotted against NA concentration. The points are the means \pm SEM of 3 separate determinations. $B$, Double-reciprocal plot of data obtained from those shown in $A$ by subtracting the values obtained at $4^{\circ} \mathrm{C}$ from those obtained at $37^{\circ} \mathrm{C}$. 

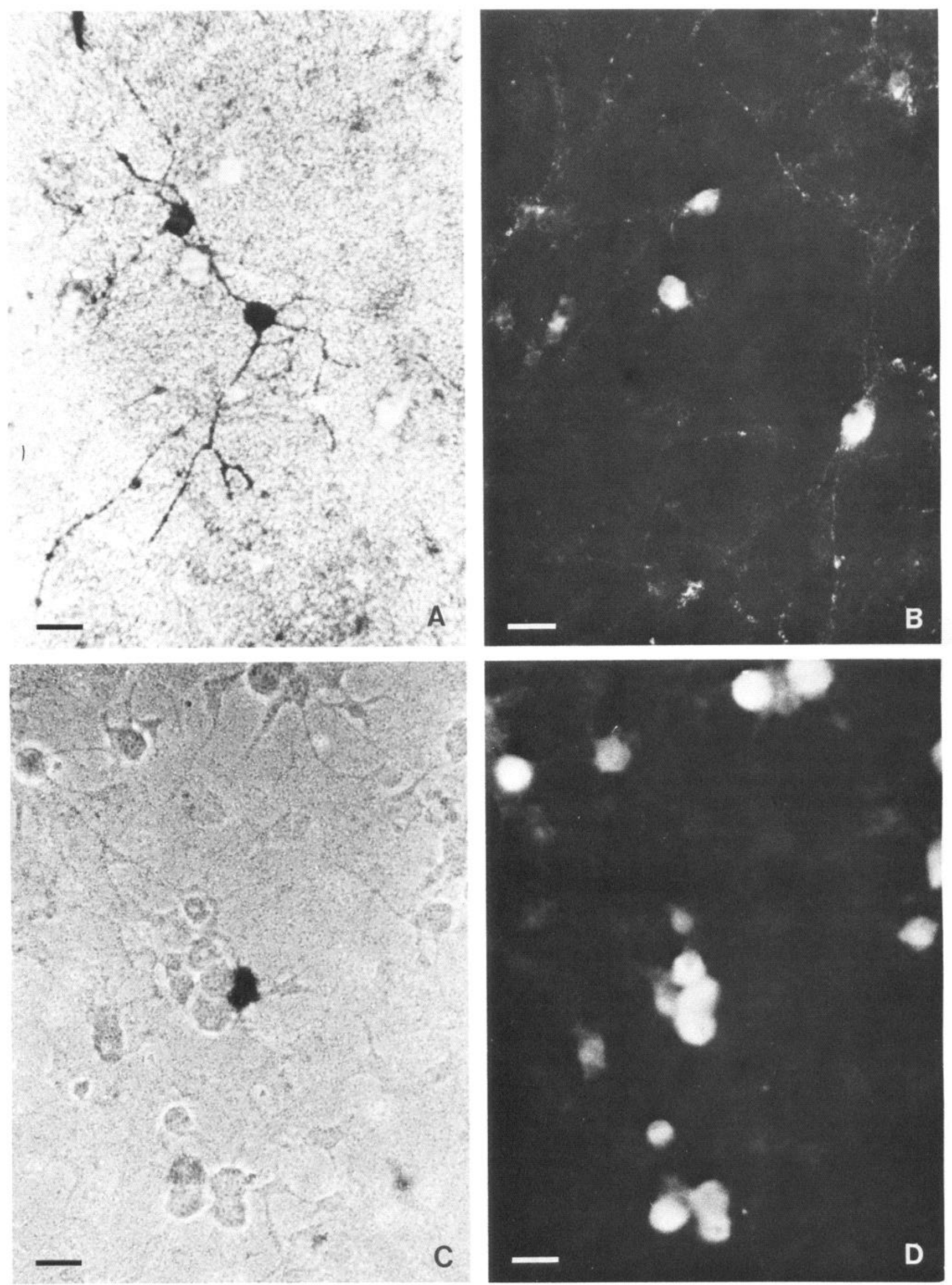

Figure 7. Non-neuronal nature of the cells taking up CA in 15 to $48 \mathrm{hr}$ cultures of E10 quail DRG. Cells taking up CA $(A)$ and those displaying substance $\mathrm{P}$ immunoreactivity $(B)$ constitute nonoverlapping populations in $2 \mathrm{~d}$ cultures. Cells accumulating ${ }^{3} \mathrm{H}-\mathrm{NA}$ in $15 \mathrm{hr}$ cultures $(C)$ do not react with antibody to neurofilament proteins $(D)$. Scale bars, $20 \mu \mathrm{m}$. 
pathetic neurons (Wakshull et al., 1978) and in some transiently TH-positive cells in fetal rat gut (Gershon et al., 1984; Jonakait et al., 1985).

Although the majority of TH-containing cells that developed in quail DRG cultures were demonstrably able to accumulate NA from the medium, a significant percentage (between 20 and $30 \%$ ) was apparently incapable of doing so. The explanation for this heterogeneity is not immediately obvious, but it should be pointed out that "uptake," as revealed by the method used in the present study, includes both transport and intracellular retention of the CA. Seemingly inactive TH-positive cells may thus not necessarily be lacking a transport system, but may be unable to store NA to any great extent. We have previously observed cell processes containing small, dense-core vesicles after permanganate fixation of DRG cultures (unpublished observations), but it cannot be determined whether all or only some of the TH-positive cells possess such organelles. Although extravesicular CA may, in certain cases, be bound selectively to cytoplasmic structures (Gershon et al., 1974), in general it is poorly retained, primarily as a result of rapid enzymic transformation to products that can diffuse readily out of the cell (Iversen, 1973; Mack and Bönisch, 1979).

The finding that the differentiation of CA-synthesizing and storing ability is accompanied by the expression of a high-affinity uptake mechanism is of interest in that it better defines the phenotype of the noradrenergic cells that develop in this DRG culture system. On the other hand, the fact that cells possessing analogous uptake properties are present within the DRG population well before the enzymes responsible for CA synthesis can be detected may be of greater relevance to an understanding of the developmental processes involved in the ontogeny of the peripheral nervous system. Our observations suggest that the cells accumulating ${ }^{3} \mathrm{H}-\mathrm{NA}$ before plating or in short-term cultures are the precursors of cells that later will express the complete noradrenergic phenotype. This filiation cannot be formally proven without accomplishing the problematic feat of isolating the postulated precursors in a pure state and following their further evolution in culture. However, several points argue in favor of the hypothesis that uptake-positive/TH-negative cells give rise to TII-positive progeny. The 2 cell types are morphologically identical and are clearly distinct from the substance P-containing neuronal population. Again, because of unavoidable losses during the working-up procedures, the counts of uptake-positive cells found in dissociated DRG before the appearance of $\mathrm{TH}$ immunoreactivity (Table 1 ) are certainly underestimates; this implies that, during the initial stages of the culture, the number of cells displaying this phenotype is greater than at later times (4-8 d), when TH-positive cells have appeared in quantity (cf. Table 1 and Fig. 3), a situation that could be indicative of a precursor-product relationship. Note that the maintenance of a pool of catecholaminergic precursors throughout the culture period is consistent with our present and previous (Xue et al., 1985b) findings that TH-containing cells arise continually in cultured DRG.

Evidence has already been presented (Le Douarin, 1984, 1986; Xue et al., 1985a, b) that the cells with autonomic potentialities (i.e., capable, under suitable conditions, of expressing the noradrenergic phenotype) that are present in sensory ganglia do not belong to the postmitotic neuronal population of these ganglia. If uptake-positive cells are indeed the precursors of the $\mathrm{TH}$ - and CA-containing cells that develop in DRG cultures, then this conclusion is strongly upheld by our demonstration that none of them exhibits neurofilament protein immunoreactivity.

The uncoupling of the expression of CA uptake and of other properties characterizing the noradrenergic phenotype has already been observed in other circumstances. Thus, evidence has been obtained suggesting that $\mathrm{TH}$-positive cells appearing transiently in fetal rat gut retain a high-affinity uptake system after they have lost their TH immunoreactivity (Jonakait et al., 1979, 1985; Gershon et al., 1984). $\Lambda$ similar persistence of CA uptake has also been described in superior cervical ganglion neurons that have switched to cholinergic function in vitro and in vivo (Reichardt and Patterson, 1977; Wakshull et al., 1978; Landis and Keefe, 1983).

As for the initial acquisition of the catecholaminergic phenotype by neural crest-derived cells, it is interesting to note that, during sympathogenesis in vivo, the capacity to take up ${ }^{3} \mathrm{H}-\mathrm{NA}$ constitutes an early marker for presumptive noradrenergic neuroblasts, which becomes demonstrable just as they reach the dorsal aorta, $12 \mathrm{hr}$ or so before fluorescence of endogenous CA can be detected (Rothman et al., 1978). The high-affinity transport system, which thus apparently precedes CA-synthesizing activity, is not restricted to neurons, for $40-50 \%$ of the nonneuronal cells of 7-12 d embryonic chick sympathetic ganglia (analyzed in conjunction with a glia-specific marker, 04, after 1 $\mathrm{d}$ of culture in vitro) were also found to take up ${ }^{3} \mathrm{H}-\mathrm{NA}$ by a DMI-sensitive process (Rohrer, 1985). Interestingly, similar results were obtained with embryonic DRG. Further differentiation of DRG cells along the catecholaminergic pathway was not described in this series of experiments, although the author considered the possibility that they were potentially of autonomic type (Rohrer, 1985; see also Rohrer and Sommer, 1983). The data we provide in the present study indicate that this is indeed the case.

\section{References}

Ayer-Le Lièvre, C. S., and N. M. Le Douarin (1982) The early development of cranial sensory ganglia and the potentialities of their component cells studied in quail-chick chimaeras. Dev. Biol. 94: 291310.

Fontaine-Pérus, J., M. Chanconie, and N. M. Le Douarin (1985) Embryonic origin of substance $P$ containing neurons in cranial and spinal sensory ganglia of the avian embryo, Dev. Biol. 107: 227-238.

Gershon, M. D., M. Hagopian, and E. A. Nunez (1974) An electromicroscopic autoradiographic study of the neuronal and extraneuronal localization of labelled amine in the heart of the bat after administration of tritiated norepinephrine. J. Cell Biol. 62: 610-624.

Gershon, M. D., T. P. Rothman, T. H. Joh, and G. N. Teitelman (1984) Transient and differential expression of aspects of the catecholaminergic phenotype during development of the fetal bowel of rats and mice. J. Neurosci. 4: 2269-2280.

Glowinski, J., and J. Axelrod (1964) Inhibition of uptake of tritiatednoradrenaline in the intact rat brain by imipramine and structurally related compounds. Nature 204: 1318-1319.

Hamberger, B., T. Malmfors, K.-A. Norberg, and C. Sachs (1964) Uptake and accumulation of catecholamines in peripheral adrenergic neurons of reserpinized animals, studied with a histochemical method. Biochem. Pharmacol. 13: 841-844.

Iversen, L. L. (1973) Catecholamine uptake processes. Br. Med. Bull. 29: $130-135$

Jonakait, G. M., J. Wolff, P. Cochard, M. Goldstein, and I. B. Black (1979) Selective loss of noradrenaline phenotypic characters in neuroblasts of the rat embryo. Proc. Natl. Acad. Sci. USA 76: 46834686.

Jonakait, G. M., K. A. Markey, M. Goldstein, C. F. Dreyfus, and I. B. Black (1985) Selective expression of high-affinity uptake of cate- 
cholamines by transiently catecholaminergic cells of the rat embryo: Studies in vivo and in vitro. Dev. Biol. 108: 6-17.

Landis, S. C., and D. Kcefe (1983) Evidence for neurotransmitter plasticity in vivo: Developmental changes in properties of cholinergic sympathetic neurons. Dev. Biol. 98: 349-372.

Le Douarin, N. M. (1984) A model for cell line divergence in the ontogeny of the peripheral nervous system. In Cellular and Molecular Biology of Neuronal Development, I. Black, ed., pp. 3-28, Plenum, New York.

Le Douarin, N. M. (1986) Cell line segregation during peripheral nervous system ontogeny. Science 231: 1515-1522.

Mack, F., and H. Bönisch (1979) Dissociation constants and lipophilicity of catecholamines and related compounds. Naunyn Schmiedebergs Arch. Pharmacol. 310:1-9.

New, H. V., and A. W. Mudge (1986) Distribution and ontogeny of SP, CGRP, SOM and VIP in chick sensory and sympathetic ganglia. Dev. Biol, 116: 337-346.

Reichardt, L. F., and P. H. Patterson (1977) Neurotransmitter synthesis and uptake by isolated sympathetic neurons in microcultures. Nature 270: 147-151.

Rohrer, H. (1985) Nonneuronal cells from chick sympathetic and dorsal root sensory ganglia express catecholamine uptake and receptors for nerve growth factor during development. Dev. Biol. 111:95107.
Rohrer, H., and I. Sommer (1983) Simultaneous expression of neuronal and glial properties by chick ciliary ganglion cells during development. J. Neurosci. 3: 1683-1693.

Rothman, T. P., M. D. Gershon, and H. Holtzer (1978) The relationship of cell division to the acquisition of adrenergic characteristics by developing sympathetic ganglion cell precursors. Dev. Biol. 65 : 322-341.

Schweizer, G., C. Ayer-Le Lièvre, and N. M. Le Douarin (1983) Restrictions of developmental capacities in the dorsal root ganglia during the course of development. Cell Differ. 13: 191-200.

Wakshull, E., M. I. Johnson, and H. Burton (1978) Persistence of an amine uptake system in cultured rat sympathetic neurons which use acetylcholine as their transmitter. J. Cell Biol. 71: 121-131.

Xue, 7. G., J. Smith, and N. M. Le Douarin (1985a) Expression du phénotype adrénergique par des cellules du ganglion rachidien de caille en culture in vitro. C. R. Acad. Sci. (Paris) 300: 483-488.

Xue, Z. G., J. Smith, and N. M. Le Douarin (1985b) Differentiation of catecholaminergic cells in cultures of embryonic avian sensory ganglia. Proc. Natl. Acad. Sci. USA 82: 8800-8804.

Xue, Z. G., J. Smith, and N. M. Le Douarin (1987) Developmental capacities of avian embryonic dorsal root ganglion cells: Neuropeptides and tyrosine hydroxylase in dissociated cell cultures. Dev. Brain Res. 34: 99-109. 